Associate membership examinations were held for 538 candidates and, in English only, for 193 holders of National Certificates in electrical engineering. Arrangements have been made with-the British Red Cross Society for prisoners of war in Germany to sit for the associate membership examination in prison camps. 1,065 national certificates and diplomas in electrical engineering were awarded during the year.

297 books and pamphlets have been added to the Institution's reference library and 58 new volumes to the lending library. Subdivision of the Journal came into effect in January 1941, Part I being distributed free to members; more than 6,000 members subscribed for Part II and some 4,000 for Part III. Science Abstracts continue to be published monthly in two sections, Section ' $A$ ', dealing with physics, and Section ' $B$ ', with electrical engineering. The universal decimal classification has now been adopted in both sections, as from January 1942 . 1,045 copies are issued each month to members and 6,720 copies per month to others.

\section{FOLK-LORE OF VENEREAL DISEASE}

TN a recent article (Brit. J. Ven. Dis., 18, $1 ; 1942$ ) Dr. J. D. Rolleston attributes the scarcity of the folk-lore literature on venereal disease partly to the fact that most medical practitioners know little and care less about folk-lore, and partly to the fact that folk-lorists are rarely medical practitioners and shrink from dealing with what they regard as an unsavoury and repulsive subject. No mention of venereal disease, for example, is to be found in W. G. Black's "Folk-Medicine" (1883) or Sir James Frazer's "Golden Bough" (3rd ed., 1927-36), the two principal works by lay writers, in which much valuable medical folk-lore is to be found, while of the two chief works in Great Britain by medical authors, namely, Pettigrew's "Superstitions Connected with the History and Practice of Medicine and Surgery", published in 1844 or two years before the term 'folk-lore' was invented by William John Thoms, does not mention venereal disease at all, and the comparatively recent work by Dan McKenzie on "The Infancy of Medicine" (1927) has only two brief references to the subject.

The only important treatise on medical folk-lore in which the subject of venereal disease is adequately discussed appears to be that of $O$. V. Hovorka and A. Kronfeld (1908-9) entitled "Vergleichende Volksmedicin". Owing to the comparatively recent establishment of their autonomy, there does not seem to be any folk-lore connected with chancroid or the fourth, fifth and sixth venereal diseases, so that Dr. Rolleston's paper deals only with syphilis and gonorrhœa.

As regards nomenelature, the term 'syphilis', which was introduced by Fracastoro in 1521, did not at first receive general recognition and during the whole of the seventeenth and eighteenth centuries only about half a dozen writers employed it. Although, however, no scientific term was given to the disease, on its first appearance in Europe a host of new names was introduced by the laity, the commonest being those indicating that the malady had originated in France. Popular theories as to its origin included the views that the disease had a divine source, being a punishment for unchastity, that it was due to intercourse between a man and an animal or that it was caused by intercourse with a woman who was menstruating or had a vaginal discharge of any kind.
Belief in a cure of a disease by transfer of it to another person or animal is a well-recognized tenet of medical folk-lore, but whereas in the case of other complaints such as epilepsy, whooping cough, warts, boils, pulmonary tuberculosis and the acute exanthemata, the transfer is purely imaginary, in venereal disease, especially gonorrhœea, it only too frequently actually takes place without, of course, having any curative effect. The person to whom the disease is transferred is preferably a young virgin of either sex, much less frequently an adult. This superstition, which dates back for several centuries, is world-wide. Other folk-lore methods of treatment for venereal disease include animal and plant remedies and miscellaneous cures which in the case of syphilis include sweating and fumigation, and local application of drugs or other substances. In the case of syphilis but not of gonorrhœa, several patron saints may be invoked, while in gonorrhœa but not in syphilis coprotherapy is sometimes employed.

\section{COLLECTIVE FARMING IN RUSSIA AND THE UKRAINE}

GIR JOHN RUSSELL has made a study of Russian agriculture, and, through his visits to that country from time to time, has been able to observe trends in agricultural policy, and the results of the State and of collective farms. He discussed his observations in a lecture recently delivered at the Royal Institution.

It was impossible to arrive at once at the most desirable system of land utilization, this being influenzed by progress in farming methods, particularly as regards mechanization, and the effect of this on the growth of the workers' interest in the State or collective unit, as opposed to his own personal stake in the land. The application of modern machinery to tillage, and of methods of livestock improvement and disease control to herds and flocks are more suited to lairge than to small units, and it is probable that success in these directions influenced the workers' views as to the extent to which they were prepared to identify their own interests with that of the large unit in which they are employed.

After the Revolution, State farms were developed, but the peasants, who expected nothing less than individual ownership of the land that they tilled, were not then sufficiently mature, either politically or technically, to make a success of this form of organization. Instead of the State farm, the collective farm figured more and more prominently in the development of Soviet land policy. Thus, by 1939 , the area occupied by collective farms was more than eleven times that of State farms.

Collectivization is based on the principle that an entire village, with its land, is run by the inhabitants as one farm, boundaries being obliterated, and the whole area divided into a few fields, the number depending on the rotation. All possessions are pooled, and the workers share the produce remaining after paying out the Government share, and meeting other obligations. Collectivization at first met with great opposition, particularly owing to the compulsory pooling of all livestock; peasants who, by years of hard work and economy, had got together a cow and a few pigs, found it difficult to have to restart from the same level as those who had never made any sacrifice to provide their families with 